\title{
Use of hematological parameters in evaluation of treatment efficacy in cutaneous leishmaniasis
}

\author{
Bilal Sula ${ }^{1}$, Recep Tekin ${ }^{2}$ \\ ${ }^{1}$ Department of Dermatology, Dicle University Medical School, Diyarbakir, Turkey \\ ${ }^{2}$ Department of Infectious Diseases and Clinical Microbiology, Dicle University Medical School, Diyarbakir, Turkey
}

\begin{abstract}
Objective: In the present study we investigated the role of hematological parameters, including neutrophil/lymphocyte ratio and platelet/lymphocyte ratio, mean platelet volume and platelet distribution width in the evaluation of treatment efficacy in adult patients diagnosed with cutaneous leishmaniasis.
\end{abstract}

Methods: The study group included 45 adult patients diagnosed with cutaneous leishmaniasis and treated as inpatients in the dermatology clinic between 2011 and 2014. A group of 45 healthy adults served as a control group.

Results: Pre- and post-treatment white blood cell count, neutrophils, and lymphocytes were significantly reduced among the patient group relative to the control group. Platelet distribution width, red cell distribution width, neutrophil/lymphocyte ratio and platelet/lymphocyte ratio were significantly elevated among the patients compared to the healthy subjects. Pre-treatment white blood cell, lymphocyte and platelet counts were significantly elevated compared to post-treatment counts among the patient cohort. Treatment was associated with reduced eosinophil count, neutrophil/lymphocyte ratio and platelet/lymphocyte ratio relative to pre-treatment status.

Conclusion: Routine hematological testing results such as platelet/lymphocyte ratio, white blood cell count, neutrophil count, red cell distribution width, platelet distribution width, and mean platelet volume may be clinically significant markers of the inflammatory state useful in the evaluation of early treatment efficacy among patients with cutaneous leishmaniasis. J Microbiol Infect Dis 2015;5(4): 167-172

Key words: Adult patient, Cutaneous leishmaniasis, Neutrophil / Lymphocyte ratio, Platelets / lymphocyte ratio

\section{Kütanöz layşmaniyaz tedavisinin etkinliğini değerlendirmede hematolojik parametrelerin kullanılması}

\section{ÖZET}

Amaç: Bu çalışmamızda kutanöz leishmaniasis tanılı yetişkin hastalarda Nötrofil/Lenfosit ve Trombosit/Lenfosit oranı, kırmızı küre dağılım genişliği, beyaz küre, ortalama trombosit hacmi, trombosit dağılım hacmi gibi kan parametrelerini ve aradaki ilişkiyi saptamayı amaçladık

Yöntemler: Bu çalışmaya 2011-2014 yılları arasında, üniversitemiz dermatoloji kliniğinde yatııılarak tedavi verilen, kutanöz leishmaniasis tanısı konulan 45 yetişkin hasta alındı. Kontrol grubu olarak 45 sağlıkı yetişkin alındı.

Bulgular: Hastaların hem tedavi öncesi hem de tedavi sonrası değerleri kontrol grubu ile karşılaştıııldığında beyaz küre, nötrofil ve lenfosit oranları istatiksel olarak anlamlı düşük bulundu. Trombosit dağılım hacmi, kırmızı küre dağılım genişliği, Nötrofil/Lenfosit ve Trombosit/Lenfosit oranı ise istatiksel olarak anlamlı yüksek bulundu. Hastaların tedavi öncesi ve sonrası değerleri karşılaştıııldığında ise tedavi öncesi beyaz küre, lenfosit ve trombosit değerleri istatiksel olarak anlamlı yüksek bulunurken eozinofil, Nötrofil/Lenfosit ve Trombosit/Lenfosit oranları istatiksel olarak anlamlı düşük bulundu.

Sonuç: Rutin olarak hemogram testi içinde kolaylıkla ölçülebilen Trombosit/Lenfosit oranı, beyaz küre, nötrofil sayısı, kırmızı küre dağılım genişliği, trombosit dağılım hacmi ve ortalama trombosit hacmi gibi parametreler kutanöz leishmaniazis hastalarında inflamatuvar durumun belirlenmesinde ve erken dönemde tedavi etkinliğinin değerlendirilmesinde kullanılabilecek belirteçler olabileceğini düşünüyoruz.

Anahtar kelimeler: Erişkin hasta, kutanöz leishmaniasis, nötrofil/lenfosit oranı, trombosit/lenfosit oranı 


\section{INTRODUCTION}

Leishmaniasis is a group of mammalian diseases caused by the intracellular parasites of the genus Leishmania and transmitted during blood-feeding by infected female sand flies (phlebotomus). Leishmaniasis is an important health issue affecting approximately 12 billion people in 88 countries around the world. The parasites enter the body through the skin and infect the cells of the reticuloendothelial system. The severity of disease results in varying clinical manifestations. The most common form is cutaneous leishmaniasis (CL). ${ }^{1,2}$ Routine CBC parameters, such as white blood cell count (WBC), neutrophil, lymphocyte and platelet counts, red cell distribution width (RDW), mean platelet volume (MPV), and platelet distribution width (PDW), are used in many settings, including the evaluation of systemic inflammation and the diagnosis and treatment of disease. Recent studies have reported changes in the circulating neutrophil, lymphocyte, and platelet counts, WBC count, MPV, PDW, neutrophil/lymphocyte ratio (NLR) and platelet/lymphocyte ratio (PLR) in cancer, inflammatory disease, and infection. Hematological changes are closely associated with the severity and the prognosis of disease. ${ }^{3-5}$

No previous study has evaluated standard hematological parameters such as NLR, PLR, RDW, WBC, MPV, and PDW in CL patients. As a result, the present study aimed to establish changes in neutrophil, lymphocyte, and platelet counts, RDW, WBC, MPV, PDW, and the NLR and PLR in CL patients.

\section{METHODS}

The present study included 45 adult patients aged 18 to 76 years who were free of comorbid chronic systemic diseases and who had been diagnosed with $C L$ based on clinical and laboratory evaluation and were followed as inpatients in the Dermatology clinic between January 2011 and December 2014. A control group consisting of 45 healthy adults aged 21 to 66 who were admitted at the outpatient dermatology clinic was also included in the study. Controls were randomly selected among healthy adults and were matched to the patient group by sex and age. In our dermatology clinic, patients with lesions greater than $2-5 \mathrm{~cm}$ and with inflammation located in the joints and the cartilage, patients with lesions resulting in chronic cosmetic problems, the patients with lesions located on the face, such as the eye- lids and lips, causing dysfunction and deformity, or $\mathrm{CL}$ patients with multiple $(>5)$ lesions were treated as inpatients. Blood samples were obtained from the antecubital vein and collected in vacuum tubes containing EDTA (15\% K3 EDTA $0.054 \mathrm{ml} / 4.5 \mathrm{ml}$ blood) and were tested within one hour. Complete blood counts were performed by an automated complete blood counter (Cell Dyn 3700). The age and gender of the patients and the pre- and posttreatment WBC, neutrophil, platelet and lymphocyte counts, NLR and PLR, RDW, PDW, and MPV were recorded and compared between the study groups.

Statistical analysis of the data was performed using the SPSS 15.0 package (SPSS for Windows 15, Chicago, Illinois, USA). Continuous variables are expressed as mean \pm standard deviation, and categorical variables are expressed as percentages (\%). Categorical variables and continuous variables were evaluated using the chi-square test and Student's t-test, respectively. Numeric data were compared using the Kruskal-Wallis test, and intra-group comparisons were made using the Mann-Whitney U-test. A P-value $<0.05$ was considered statistically significant.

\section{RESULTS}

Among the 45 patients diagnosed with $\mathrm{CL}, 31$ $(68.9 \%)$ were female and $14(31.1 \%)$ were male. The age of the patients ranged from18 to 76 years. The mean age of the patients was $46.73 \pm 18.35$ years. The control group consisted of 45 subjects ranging in age from 21 to 66 years, and included 17 $(37.8 \%)$ male and $28(62.2 \%)$ female patients. The mean age of the healthy subjects was $46.0 \pm 13.0$ years.

The most common localization of the lesion was the nose, upper extremity (forearm, dorsal hand) and cheeks (Figure 1). The number of lesions in a single patient ranged from 1 to 10 ; the mean lesion number was 2.7. The duration of disease ranged from one to 36 months and the mean duration of disease was $8.7 \pm 8.6$ months. Intramuscular (IM) meglumine antimoniate (Glucantime) $10-20 \mathrm{mg} / \mathrm{kg} /$ day was administered in 37 patients. Intravenous (IV) sodium stibogluconate (Pentostam) $10-20 \mathrm{mg} /$ $\mathrm{kg} /$ day was administered in 10 patients. Both Glucantime and Pentostam were administered to two patients. Patients received Glucantime/Pentostam at a mean dose of 13.8 day. The demographics and the clinical features of the patients are summarized in Table 1. 


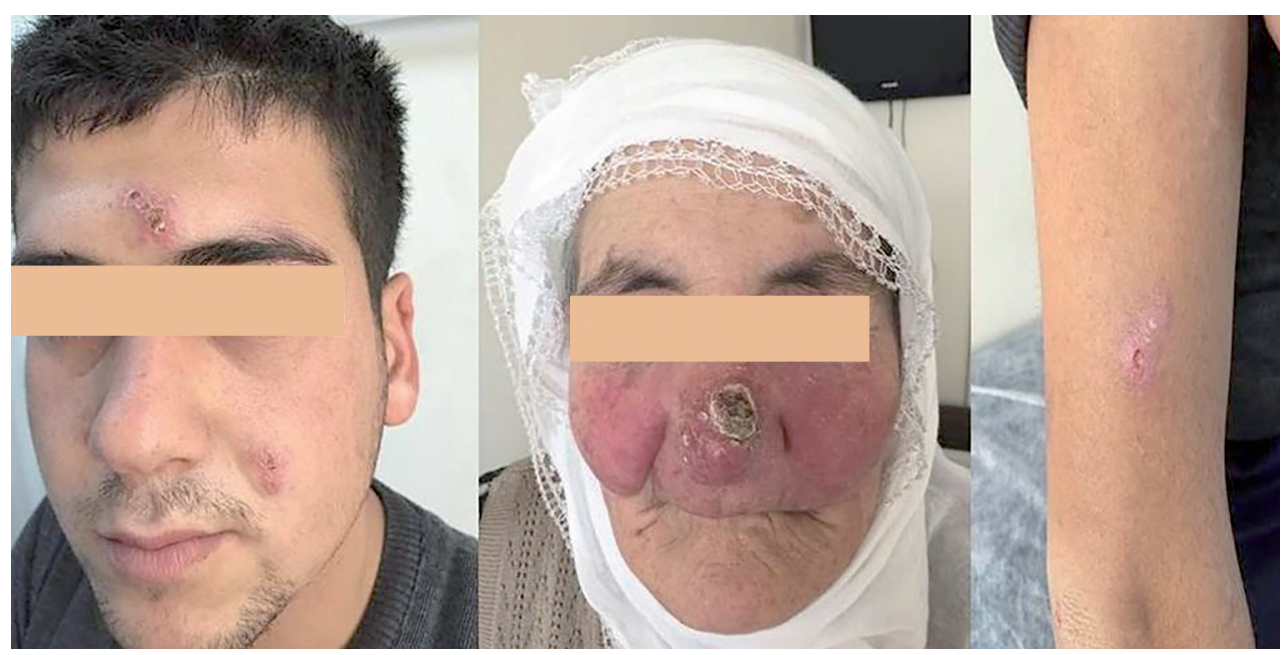

Figure 1. Erythematous, ulcerated nodular lesions covered with black crusts on nose, upper extremity, forehead and cheek.

Table 1. Demographic and clinical characteristics of patients

\begin{tabular}{|c|c|c|c|}
\hline & Patient (n) (Mean) & & Patient (n) (Mean) \\
\hline Gender & & Ear & 2 \\
\hline Female & 31 & Nose & 17 \\
\hline Male & 14 & Lip & 1 \\
\hline Age (year) & $46.73 \pm 18.35$ & Upper extremity & 14 \\
\hline Duration of disease (month) & 8.73 & Lower extremity & 5 \\
\hline Number of lesion & 2.71 & Similar disease history & 3 \\
\hline Localization & & Meglumine antimonate IM & 37 \\
\hline Forehead & 7 & Sodium stibogluconate IV & 10 \\
\hline Eyelid & 3 & Average dose (day) & 13.77 \\
\hline Cheek & 12 & & \\
\hline
\end{tabular}

Table 2. Evaluation of hemogram parameters in the patient and control groups

\begin{tabular}{|c|c|c|c|c|c|c|}
\hline Parameters & $\begin{array}{l}\text { Pretreatment } \\
\text { (Mean } \pm S D)\end{array}$ & $\begin{array}{c}\text { Control } \\
\text { (Mean } \pm S D)\end{array}$ & $\mathbf{p}$ & $\begin{array}{l}\text { Posttreatment } \\
\text { (Mean士SD) }\end{array}$ & $\begin{array}{c}\text { Control } \\
\text { (Mean } \pm S D)\end{array}$ & p \\
\hline WBC (K/uL) & $6.99 \pm 2.27$ & $9.75 \pm 2.07$ & 0.000 & $5.99 \pm 1.91$ & $9.75 \pm 2.07$ & 0.000 \\
\hline Neutrophil (K/uL) & $4.22 \pm 1.93$ & $5.71 \pm 1.47$ & 0.000 & $3.77 \pm 1.58$ & $5.71 \pm 1.47$ & 0.000 \\
\hline Lymphocyte (K/uL) & $2.04 \pm 0.74$ & $3.50 \pm 0.92$ & 0.000 & $1.53 \pm 0.59$ & $3.50 \pm 0.92$ & 0.000 \\
\hline Platelets (K/uL) & $269 \pm 74.21$ & $264 \pm 101.32$ & 0.815 & $247 \pm 66.30$ & $264 \pm 101.32$ & 0.333 \\
\hline MPV (fL) & $7.96 \pm 1.21$ & $7.60 \pm 1.25$ & 0.160 & $8.01 \pm 1.31$ & $7.60 \pm 1.25$ & 0.130 \\
\hline PDW (\%) & $17.58 \pm 1.11$ & $11.06 \pm 3.36$ & 0.000 & $17.69 \pm 1.36$ & $11.06 \pm 3.36$ & 0.000 \\
\hline RDW (\%) & $15.08 \pm 1.46$ & $12.62 \pm 1.49$ & 0.000 & $15.29 \pm 1.67$ & $12.62 \pm 1.49$ & 0.000 \\
\hline NLR & $2.23 \pm 1.14$ & $1.66 \pm 0.32$ & 0.002 & $2.83 \pm 1.73$ & $1.66 \pm 0.32$ & 0.000 \\
\hline PLR & $140.83 \pm 41.38$ & $81.46 \pm 40.34$ & 0.000 & $182.64 \pm 76.84$ & $81.46 \pm 40.34$ & 0.000 \\
\hline
\end{tabular}

NLR: Neutrophil / Lymphocyte Ratio, PLR: Platelet/Lymphocyte Ratio, SD: Standard Deviation 
When the pre- and post-treatment hematological results were compared among the patients and control subjects, WBC, neutrophil, and lymphocyte counts were significantly reduced among the patients. PDW, RDW, NLR, and PLR were significantly elevated in the patient group. There was no significant difference in platelet count or MPV among the study groups. When the pre- and post-treatment hematological results were compared among the patients, pre-treatment WBC, lymphocytes, and platelets were significantly increases, whereas the eosinophils, and NLR and PLR were significantly lower prior to clinical treatment of the disease. There was no significant correlation between neutrophil, MPV, PDW, and RDW (Tables 2, and 3).

Table 3. Evaluation of hemogram parameters in the patients

\begin{tabular}{lccc}
\hline Parameters & $\begin{array}{c}\text { Pretreatment } \\
\text { (Mean } \pm \text { SD) }\end{array}$ & $\begin{array}{c}\text { Postreatment } \\
\text { (Mean } \pm \text { SD) }\end{array}$ & p \\
\hline WBC (K/uL) & $6.99 \pm 2.27$ & $5.99 \pm 1.91$ & 0.000 \\
Neutrophil (K/uL) & $4.22 \pm 1.93$ & $3.77 \pm 1.58$ & 0.066 \\
Lymphocyte (K/uL) & $2.04 \pm 0.74$ & $1.53 \pm 0.59$ & 0.000 \\
Eosinophils (K/uL) & $0.19 \pm 0.18$ & $0.26 \pm 0.27$ & 0.035 \\
Platelets (K/uL) & $269 \pm 74.21$ & $247 \pm 66.30$ & 0.018 \\
MPV (fL) & $7.96 \pm 1.21$ & $8.01 \pm 1.31$ & 0.731 \\
PDW (\%) & $17.58 \pm 1.11$ & $17.69 \pm 1.36$ & 0.585 \\
RDW (\%) & $15.08 \pm 1.46$ & $15.29 \pm 1.67$ & 0.189 \\
NLR & $2.23 \pm 1.14$ & $2.83 \pm 1.73$ & 0.044 \\
PLR & $140.83 \pm 41.38$ & $182.64 \pm 76.84$ & 0.000 \\
\hline
\end{tabular}

NLR: Neutrophil / Lymphocyte Ratio, PLR: Platelet/Lymphocyte Ratio SD: Standard Deviation

\section{DISCUSSION}

Leishmaniasis is an important public health issue affecting billions of people around the world. ${ }^{1}$ Leishmaniasis is endemic in Southeastern Anatolia and in the Mediterranean regions of Turkey, and is considered a major health challenge. ${ }^{1}$ The disease has a wide clinical spectrum that includes asymptomatic disease, cutaneous, mucocutaneous, and visceral leishmaniasis as a result of various parasite- and host-related factors. Leishmaniasis lesions begin as an erythematous papule and develop into a nodule of 1-2 cm in diameter within a few months. Later, this nodule progresses to an ulcerative lesion that may be crusted over. If left untreated, these lesions can heal spontaneously within 1-1.5 years. However, scarring in patients with lesions located on the face, especially the nose, ears, and eyelids, often results in cosmetic problems and facial dysfunction. ${ }^{1,2}$

Recent studies on the pathogenesis of Leishmaniasis have shown that neutrophils migrate to the infection site within the first 30 minutes following the passage of the parasite into the body and begin to phagocytose parasites at the site of infection. Neutrophils facilitate parasite elimination through the secretion of cytokines, chemokines, LTB-4, and neutrophil-derived extracellular antimicrobial peptides. Additionally; reduced acute neutrophilic infiltration results in improved host defense against the parasite. ${ }^{6-8}$ Furthermore, the clinical course of the disease is characterized by the balance between the activation of a set of cytokines (IL-2, IFN- $\gamma$, TNF- $\alpha$ ), most of which are produced by Th-1 T-cells, and the deactivation of other cytokines (IL-4, IL-5, IL-13) produced by the other regulatory T-cells. ${ }^{2,8,9}$ Hematological disorders may also occur in cases of systemic leishmaniasis and may include anemia, thrombocytopenia, and pancytopenia. ${ }^{1}$ Previous studies have reported that neutropenia occurs in leishmaniasis due to the destruction of neutrophils in the enlarged spleen and changes in the circulating polymorph nuclear leukocytes (PNL). Pancytopenia develops as a result of the rapid destruction of blood cells covered with membrane-derived antiplatelet, anti-neutrophilic and anti-erythrocyte lgG antibodies. A significant reduction in the bone marrow PNL reserve has been reported to occur in some patients. Anemia is believed to result from ineffective erythropoiesis and the phagocytosis of immature erythroblasts caused by macrophage hyperactivity in the bone marrow. ${ }^{10,11}$ The lymphocyte count is reduced due to increased lymphocyte apoptosis in cases of chronic infection. Again, an ongoing inflammatory process results in an increased number of megakaryocytes and a relative thrombocytosis. ${ }^{12}$

Recently, several markers have been in used to measure the systemic inflammatory state. The NLR has been used to evaluate the systemic inflammatory response in many conditions, including cardiovascular diseases, diabetes mellitus, metabolic syndrome, local or systemic infection, and cancer (lung, ovarian, and colorectal). ${ }^{13-15}$ Sen et al. Reported increased neutrophil count and NLR, and reduced lymphocyte count among patients with psoriasis relative to a control group. ${ }^{14}$ Ataseven et al. conducted a study involving 104 psoriasis patients demonstrating significant elevations in leukocyte and neutrophil counts and the NLR among the patient group. ${ }^{16}$ The authors suggested that hematologic parameters might be used as a simple, 
affordable, and useful marker for disease follow-up and the assessment of systemic inflammation in psoriasis. Lymphocyte count and NLR were correlated with parasitemia in a study of 440 Dutch patients diagnosed with malaria; however blood count data was not a significant marker of clinical severity in patients treated in the intensive care unit. Evaluation of the NLR together with lymphocytopenia was a more effective marker of bacteremia than the total leukocyte count and CRP. ${ }^{17}$ A Japanese study of 266 hepatocellular carcinoma patients treated with hepatic arterial infusion chemotherapy was reported an improved response to treatment among patients with lower NLR. NLR may be a useful marker for evaluating the response to treatment. ${ }^{18}$ Gokmen et al. conducted a study involving 96 ankylosing spondylitis patients and 81 healthy subjects, measuring NLR before and after anti-TNF- $\alpha$ treatment. Pre-treatment NLR was higher in the patients relative to the control group, whereas post-treatment NLR was reduced relative to control subjects. NLR was therefore beneficial in evaluating the efficacy of anti-TNF- $\alpha$ treatment in suppressing inflammation when used in combination with other acute phase reactants such as CRP. ${ }^{19}$ No previous studies have evaluated NLR in CL. The present study demonstrates that both pre- and post-treatment NLR is higher among Leishmaniasis patients relative to the control group. NLR was increased following treatment. WBC, neutrophil, and lymphocyte counts were lower compared to the control group in both the pre- and post-treatment samples. These results are consistent with prior studies conducted in other diseases.

MPV is one of the most commonly studied markers of platelet activation. Recently, new platelet indicators such as PDW, a quantitative marker of platelet volume, have been evaluated as prospective markers of platelet activation..$^{20}$ Previous studies have shown that increased MPV reflects both systemic inflammatory activity and the treatment response, and is closely correlated with local inflammation. ${ }^{21}$ Previous studies have demonstrated that MPV is increased in cardiovascular diseases such as myocardial infarction, stroke, and peripheral arterial disease, whereas it is unclear what changes may occur in rheumatic diseases. PDW is useful in distinguishing reactive thrombocytosis and essential thrombocythemia.22,23 PLR is associated with poor prognosis in several cancers and cardiovascular diseases. ${ }^{24}$ Yuce et al. evaluated MPV before and after the cobalamin treatment in 204 patients with vitamin B12 deficiency, and reported that MPV is significantly increased post-treatment, whereas the platelet count is decreased. ${ }^{25}$ An Iranian study established higher platelet counts and lower MPV levels in the active period of inflammatory and infectious diseases relative to the recovery period in a study of 100 pediatric patients. They suggested that these markers may be used as reliable markers of disease activity and for evaluation of the treatment response. ${ }^{4} \mathrm{~A}$ study by Bozkurt et al. investigated pre- and post-treatment MPV and RDW levels in patients with brucellosis, reporting decreased MPV and RDW during the pre-treatment phase relative to the post-treatment period. Again, ESR, MPV, RDW, hemoglobin, CRP, PLT, and WBC differed significantly among the study groups. ${ }^{5}$ Boyraz et al. Evaluated 105 ankylosing spondylitis (AS) patients receiving anti-TNF- $\alpha$ treatment and found no significant difference in NLR compared to the control group. However, they reported a significant reduction in PLR. TPLR may be a useful marker for clinical follow-up and the identification of sub-clinical inflammation in AS patients. ${ }^{24}$ Another study evaluated rheumatoid arthritis patients in remission and included both and found a significant difference in the platelet, lymphocyte, and neutrophil counts in anti-TNF- $\alpha$ treated patients relative to healthy subjects, whereas there was no significant difference in NLR and PLR. Based on these findings, they concluded that antiTNF- $\alpha$ treatment achieved a complete inflammatory suppression in RA patients. ${ }^{26}$ Kılıncalp et al. evaluated144 patients diagnosed with colorectal cancer, reporting that NLR, PLR, and the MPV levels were significantly elevated in the patient group. The authors suggested that this parameter might be used at the postoperative follow-up and in general population screening. ${ }^{15}$ No previous study has evaluated MPV, RDW, and PLR in patients with CL. We found that pre-treatment PLR and PDW are higher among leishmaniasis patients relative to the control group, whereas MPV levels are not significantly different. Additionally, pre-treatment PLR was lower compared to the post-treatment group.

In conclusion, parameters measured during routine CBC testing, such as PLR, WBC, neutrophil count, RDW, PDW, and MPV may be used as markers of the inflammatory state in patients with $\mathrm{CL}$. Furthermore, we suggest that these parameters may provide insight in the evaluation of early treatment efficacy. However, large-scale studies are required to further clarify the use of these parameters in clinical practice. 


\section{DISCLOSURES}

Financial disclosure statements have been obtained, and no conflicts of interest have been reported by the authors or by any individuals in control of the content of this article.

\section{REFERENCES}

1. Uzun S: Leishmaniasis. Dermatology. Ed. Tüzün $Y$, Gürer MA, Serdaroğlu S, Oğuz O, Aksungur VL. 3rd edition, Istanbul, Nobel Tıp Kitabevi, 2008;659-682.

2. Mansueto P, Seidita A, Vitale G, Cascio A. Leishmaniasis in travelers: A literature review. Travel Med Infect Dis 2014;12(6PA):563-581.

3. Zahorec R. Ratio of neutrophil to lymphocyte counts-rapid and simple parameter of systemic inflammation and stress in critically ill. Bratisl Lek Listy 2001;102:5-14.

4. Zareifar S, Farahmand Far MR, Golfeshan F, Cohan N. Changes in platelet count and mean platelet volume during infectious and inflammatory disease and their correlation with ESR and CRP. J Clin Lab Anal 2014;28:245-248.

5. Bozkurt F, Aslan E, Deveci Ö, Tekin R. Evaluatıon of mean platelet volume levels in patients with brucellosis. Anatol J Clin Investig 2014;8:126-129.

6. McConville MJ, Naderer T. Metabolic pathways required for the intracellular survival of Leishmania. Annu Rev Microbiol. 2011;65:543-561.

7. Ribeiro-Gomes FL, Sacks D. The influence of early neutrophilLeishmania interactions on the host immune response to infection. Front Cell Infect Microbiol 2012;2:59.

8. da Silva Santos C, Brodskyn Cl. The Role of CD4 and CD8T Cells in Human Cutaneous Leishmaniasis. Front Public Health 2014;2:165.

9. Ribeiro-Gomes FL, Peters NC, Debrabant A, Sacks DL. Efficient capture of infected neutrophils by dendritic cells in the skin inhibits the early anti-leishmania response. PLoS Pathog 2012;8: e1002536.

10. Rai ME, Muhammad Z, Sarwar J, Qureshi AM. Haematological findings in relation to clinical findings of visceral Leishmaniasis in Hazara Division. J Ayub Med Coll Abbottabad 2008;20:40.

11. Marwaha N, Sarode R, Gupta RK, et al. Clinico-hematological characteristics in patients with kala azar. A study from north-west India. Trop Geogr Med 1991;43:357.

12. Yüksel M, Yıldız A, Oylumlu $M$, ve ark. The association between platelet/lymphocyte ratio and coronary artery disease severity. Anatol J Cardiol. 2015;15:640-647.

13. Balta S, Demirkol S, Unlu M, et al. Neutrophil to lymphocyte ratio may be predict of mortality in all conditions. $\mathrm{Br} \mathrm{J}$ Cancer 2013;109:3125-3126.
14. Sen BB, Rifaioglu EN, Ekiz O, et al. Neutrophil to lymphocyte ratio as a measure of systemic inflammation in psoriasis. Cutan Ocul Toxicol 2014;33:223-227.

15. Kilincalp S, Coban S, Akinci H, et al. Neutrophil/lymphocyte ratio, platelet/lymphocyte ratio, and mean platelet volume as potential biomarkers for early detection and monitoring of colorectal adenocarcinoma. Eur J Cancer Prev 2015;24:328333.

16. Ataseven A, Bilgin AU, Kurtipek GS. The importance of neutrophil lymphocyte ratio in patients with psoriasis. Mater Sociomed 2014;26:231-233.

17. van Wolfswinkel ME, Vliegenthart-Jongbloed K, de Mendonça Melo M, et al. Predictive value of lymphocytopenia and the neutrophil-lymphocyte count ratio for severe imported malaria. Malar J 2013;12:101.

18. Terashima T, Yamashita $\mathrm{T}$, lida $\mathrm{N}$, et al. Blood neutrophil to lymphocyte ratio as a predictor in patients with advanced hepatocellular carcinoma treated with hepatic arterial infusion chemotherapy. Hepatol Res 2014; doi: 10.1111/hepr.12436.

19. Gökmen F, Akbal A, Reşorlu H, et al. Neutrophil-Lymphocyte Ratio Connected to Treatment Options and Inflammation Markers of Ankylosing Spondylitis. J Clin Lab Anal 2014; doi: 10.1002/jcla.21768.

20. Vagdatli E, Gounari E, Lazaridou E, et al. Platelet distribution width: a simple, practical and specific marker of activation of coagulation. Hippokratia 2010;14:28-32.

21. Akarsu S, Kurt ANÇ, Kurt A, et al. Thrombocyte volume parameters in different disease groups. Türk Pediatri Arşivi 2006;41:208- 213.

22. Yazici S, Yazici M, Erer B, et al. The platelet indices in patients with rheumatoid arthritis: mean platelet volume reflects disease activity. Platelets 2010;21:122-125.

23. Wiwanitkit V. Plateletcrit, mean platelet volume, platelet distribution width: its expected values and correlation with parallel red blood cell parameters. Clin Appl Thromb Hemost 2004;10:175-178.

24. Boyraz I, Koç B, Boyacı A, et al. Ratio of neutrophil/lymphocyte and platelet/lymphocyte in patient with ankylosing spondylitis that are treating with anti-TNF. Int J Clin Exp Med 2014;7:2912-2915.

25. Yüce $S$, Cüre MC, Cüre E, et al. Evaluation of Mean Platelet Volume Before and After Cobalamin Treatment in Patients with Vitamin B12 Deficiency. Cukurova Medical Journal 2014;39:329-335

26. Boyraz I, Boyaci A, Koc B, et al. The ratio Neutrophil/Lymphocyte and Platelet/Lymphocyte in patient with Rheumatoid Arthritis that are Treating with Anti-TNF. Acta Med Anatol 2014;2:93-96. 